\title{
Eco-Spirituality in Alice Walker's The Colour Purple
}

\author{
Dr. Santosh Kumari \\ Associate Professor, Department of English \& Foreign Languages, MDU, Rohtak
}

\begin{abstract}
Alice Walker, a proponent of eco-spirituality, endeavors to usher the flourishing spirit of solidarity and Justice through little acts of earthly functions which may transform our environment and adorn the surroundings with heavenly touch of natural beauty. Earthly delights always in abundance, revel and recognize wholeness and integrity, though unfortunately it is man himself who never bothers to explore and avail the worshipful treasures of bliss on this planet. Walker as an eco-spiritualist attempts to relocate the redemptive springs of earthly clinging that evidently protects and nourishes human family without any abuse or exploitation.
\end{abstract}

Keywords: Ecospirituality, Vedanta, Christianity, Ethos

Walker's vision of eco-harmony reconfigures mutual relationships for greater health, and is inclusive of entire nature, cosmos and all creatures on this earth. It emphatically seems to reestablish the Vedanta gospel of "Vasudhev Kutumbkam" that is the whole universe is a single family. Walker's philosophical stance indeed, propagates consummation of value-laden generosity of earthly power that may reconstruct progressive social order. The spiritual and moral ethos need not to be fascinated by the church-loving image of God, the validity of Christianity is rather viewed through self investment of righteousness. The constrained codes of religious activities are most frequently practiced with set norms of emotionless dedication, while the true love for God needs just simplifying our life style with honesty at the core of heart. The intrinsic value of universal love vigorously signals earth saving eco-justice that is undeniably as important as racial justice and human rights.

Walker's eco-spiritualist credo seems best elaborated in her Pultizer Prize winning novel The Colour Purple. Shug, the blue singer in the novel awakens Celie towards true Christianity that supports resistance to fight against dehumanizing hostile forces. Celie has been brutalized and silenced by Alphonso, her step father who repeatedly raped and impregnated her. Even her children are separated and sold away by Alphonso. Patriarchy whips her further when Celie is warned, "You better not never tell nobody but God, I would kill your mammy... when that hurt, I cry. He start to choke me saying you better shut up and git used to it" (3). Unfolding her woeful tale to Christian God, the only man she knows, Celie writes, "I am fourteen year old, I have always been a good girl. May be you can give me a sign letting me know what is happening to me"(3). Her early letters to God emphatically reveal that church as an integral part of community, dictates moral values to human societies. Celie, resigns herself to Alphonso, the beast, as her mother's reaction to the pressure of circumstances is cool and indifferent. Her capacity to suffer the demeaning behavior ,brutalities and indignities, utterly shatters her self-possession. She is completely dispossessed of her "self" and survives only by sinking into a numb state. She looks an 'ineffectual shadow' like figure, a 'streak' of helplessness and ignominy. She reflects infinite apathy to suffer. However, the same barbaric treatment and cruelty is witnessed in the The Third Life Of Grange Copeland when Brownfield like his father terrorizes his wife, the educated Mem. "He wanted her to talk but to talk like what she was; a hopeless nigger woman who got her ass beat every Saturday night. He wanted her sound like woman who deserted him" (81).

Walker is preoccupied with the exposure of psychic and physical pains of black women. Emphasizing their longing for freedom, creativity and spirituality, Walker challenges their role in the patriarchal system. As a womanist and spiritualist, Walker is obviously committed to probe into the oppression of black women and her obsession can be identified through her authorial voice in The Color Purple. In her interviews Walker frequently spoke of brutality and violence in the lives of black women, many of whom were grown with her at Eatonton in Georgia. As a consequence of forced indoctrination of male dominance and consistent brainwashing, black women fail to secure their identity. Social victimization retreats them from their personal ambitions and dreams. Their passive submission to the regimented authority of violent males leaves them utterly helpless.

However, diligent search for self-situated "honour" consistently manifests thematic evolution and relevance of blurring issues. An intense battle between an individual's dreams and frustrations, and his agonizing 
desire to resist and control the adverse environment, is very gripping and realistic. Most of Walker's leading characters look sensitive and intelligent, and try to withstand the pressure of degrading realities around them. They indulge in act of aggression and tend to compensate the loss of their dreams and fantasies by denying subjugation to racial and sexual dominance. Walker probes into the causes of pains and pathos in the life of black women. Her perception and presentation both leave a stirring effect and reveal death like agony with profound complexity in the most conceivable manner. Her depiction of the helpless victims infact, voices her protest against the instruments of oppression. Celie is brought up in unhealthy and unhygienic atmosphere and is grown apathetic to poverty, ignorance and brutality. The Colour Purple is a globally acclaimed epistolary novel and the letters written to God by Celie, make the reader to feel the agony of Celie's soul. Celie's poor grammar and misspellings accurately reflect her restlessness and quest for independence. Her predicament has to be ended. She emerges truly heroic, courageous and enviable only when she kicks back her oppressor and struggles to honour her integrity. She is strikingly transformed and looks a self-reliant challenging woman. Celie, who remained non-existent and vulnerable to sexual and emotional assault, and is forced to bear injustice, is resolved to fight back. Her careful nursing of Shug, who had been ailing from a womanly disease, wins her Shug's love and friendship. The two grow intimate and share their miseries. Shug awakens Celie to her own strength and sensuality and excites her beyond bounds. With tender caring and loving songs, Shug reveals Celie ,"God is not the big and old and tall and graybearded and white," (175). God is an omnipotent expansive power of trees, fields, birds and air who "love all them feelings," God who "love everything you love" and "love admiration but more than anything else, God love admiration ... just wanting to share a good thing" (1).

Walker's concept of eco-spirituality is earthly and love making, and through her writings, she strongly condemns waste and depredation of natural assets. In The Temple Of My Familiar also, Walker seems a high priestess of earthly mother whose tender caring motivates us to nourish inner strength, virtuousness and generosity. Fanny in the novel elaborates a series of twenty seven gospels of compassion and tolerance and states:

To them will be given the insight that every good act done anywhere in the cosmos welcomes the life of an animal or a child.... Helped are those who are shown the existence of the Creator's magic in the Universe; They shall experience delight and astonishment without ceasing.... Helped are those who find the courage to at least one small thing each day to help the existence of another - plant, animal, river, or human being (290-291)

This unconditional love for all, leads to contentment and creativity, and nature in abundance showers its love and care. In The Same River Twice, walker writes "wildness means following the growth of love / like a plant that reached through stone toward the sun" (171-172). Walker's notion of eco-spirituality is more than a celebration of environmental health, beauty and sensuality. It is a magnetic life force, and true Christianity as Sam Keen States, "defined the ultimate reality - God as love - an erotic vision" (26) which subscribes an intuitive urge for bonding and universality. Through her writings, Walker raises her voice against all those institutions, traditions, and theological perceptions which seek to destroy the dignity of individual in relation to environmental ethical codes. To liberate her women from the 'claptrap of theology', Walker insists to determine the quality of real existence and participation in the fullness of life. God can not be confined to institutional boundaries of church, it is a supreme power that pulsates through the whole creation. The Christian God in The Color Purple acts like other men and fails to help Celie. Her deliverance begins only when she stops looking at God for help and steers the course of her life herself. With the help of a woman of flesh and blood like Shug Avery, Celie is radically transformed and loses all faith in the image of Christian God. In contrast to conventional attitude, Celie like Meridian demands reconstruction of the fragmented existence and establishes affinity with nature and her own heritage in a new context.

However, freedom from the strangulating hold of the hypocrisy of traditional Christianity can not be attained without the freedom of physical existence. Celie in The Colour Purple shares her pain with the Christ through her letters only because she is too ashamed to talk about what is happening with her. But once she wins the love of Shug, her image of God begins to shatter. Shug assures her that God is not a white male with long flowing hair and grey beard. God is a life force that imbibes through the whole world, all human beings, all nature, the flowers, the leaves, and even a "snake." Religion is attuned to the interconnectivity with nature. God pulsates through the green earth and the blue sky, blowing winds and running waters. Walker emphatically convinces the reader through Shug "I think it pisses God off if you walk by the colour purple, in a field, somewhere and don't notice it"'(177). Shug further states: 
My first step from the old white man was trees. Then air. Then birds. Then other people. One day when I was sitting quiet and feeling like a motherless chile which I was, it came to me; like that feeling of being part of everything, not separate at all. I knew that if I cut a tree, my arm would bleed. And I laughed and I cried and I run all round the house. ... Everything want to be loved. Us sing and dance, make faces and give flower bouquets, trying to be loved....Y You ever notice that trees do everything to git attention we do, except walk? ... I never teruly notice nothing God make. Not a blade of corn (how it do that?) not the color purple (where it come from?) Not the little wildflowers, nothing. .... Man corrupt everything, (176-177).

This connectivity of human emotions with nature expands one's spiritual vision towards godly beauty permeating through every little bit of eco-adornments True Christ according to Walker, nourishes broad perception of oneself. She also believes in the presence of protective spirits - not essentially the angels of Judaeo-christian freedom, but the spirit of nature, that is utterly crucial for human survival. Walker writes in Living By The Word, "the feeling of being loved and supported by the universe general and by certain recognizable sprits is bliss. No other state is remotely like it" (98).

In The Colour Purple Walker reaffirms her joyous acceptance of the curative power of earth, and asserts that our persistent efforts must recognize each unit of environment as part of human family so that spirituality and flowing freedom may flourish. Through the authorial voice of Shug in The Colour Purple, the reader's vision of religious discernment and discipline is expanded. As Trudy Bloser Bush observes, "Shug develops the holistic consciousness of the Christian mystics.... she realizes that God is inside each person; people come to church to share, not find God" (103).

Walker's writings have been an expression of splendor and flourishing love for eco-friendly perspective in life. Her poetry, short stories, novels, essays, and even documentaries, all seem immersed in earthly motifs which evidently enhance generosity and endurance in human relationships. However, her recurrent consummation of Earth and Nature may seem discomfiting to the mainstream of traditional churchloving Christians, but her philosophy as Henry C. Sinmmons observes, widens the image of God and gives "new life stories of God," and devises new "language about God" which may establish "the many sacred presences of God in history and established religion" $(354,358)$. Walker believes in transformation of an individual's outlook so that justice, truthfulness, compassion and equality may prevail on earth. Walker rejects the hypocrisy of the organized religion and emphasizes the need of forgiveness, tolerance and life - giving pleasures. She acknowledges every gesture of mutuality and every act of resistance that may bring blessed change in human society. She redefines the role of Christ and presents the historical Jesus as one among many beloved innocent children. Representing ancestral heritage and wisdom, Walker writes, "I further maintain that Jesus most of us have been brought up to adorn must be expanded to include the "wizard" and the dancer, that which this is done, it becomes clear that they coexist quite easily with pagan indigenous people... our ancestors ... already practiced, the love and sharing that he preached" (ALS, 25).

The concept of eco-spirituality as illustrated in Walker's writings, seems committed to ethical perspective that inevitably emerges through a perfect harmony between man and nature. The Colour Purple also celebrates earthly delights. Though the novel is replete with instances of brutalization and humiliation, but the story ends with a rejoicing note of forgiveness and welfare of all people, both male and female. The novel voices Walker's strong conviction in Earth-saving and people-loving approach in life. Her indefatigable trust in eco-spirituality, and her efforts to establish peace and justice through blissful lauds between man and nature, invite the reader to join this venture of ethical decorum, though the "journey" is "hazardous" but "guaranteed to work the heart into a bolder shape" (WM, 3).

\section{References}

[1]. Bush, Trudy Bloser. “Transforming Vision: Alice Walker And Zora Neale Hurston,” Christian Century 105 (1988): 103-9. Print

[2]. Sam Keen. The Passionate Life: Stages of Loving. New York: Harper and Row, 1983. Print

[3]. Simmons, Henry C. "Reflections on The Color Purple: Losing and Finding God in Non-Male Images.” Living Light 25 (1989): 356 , 358. Print

[4]. Walker, Alice. Anything We Love Can Be Saved: A Writer's Activism. New York: Random House 1997. Cited hereafter as ALS. Print

[5]. The Color Purple. New York: Pocket Books, 1982. Cited hereafter as CP. Print

[6]. Living by the Word. New York: Harcourt Brace Jovanovich, 1988. Cited hereafter as LBW. Print

[7]. The Same River Twice. New York: Scribner, 1996. Cited hereafter as SRT. Print

[8]. The Temple of My Familiar. New York: Pocket Books, 1989. Cited hereafter as TMF. Print 